


\title{
Glocalization: An Analytical Path Towards Inclusive Contemporary Art?
}

\author{
Lina Abazine
}

\begin{abstract}
'It is a commonplace of the current historical thinking about globalization to say: There are no vantage points from which to observe any culture since the very processes of globalization have effectively abolished the temporal and spatial distance that previously separated cultures. Another way this thinking has been expressed is in the idea of globalization as the mode and ultimate structure of singularization, standardization, and homogenization of culture in service of instruments of advanced capitalism and neoliberalism' (Enwezor 2003, 57).
\end{abstract}

The process of globalization has been famously described by the anthropologist Arjun Appadurai in his book Modernity at Large (Appadurai 1996), which focused on the cultural dimensions of globalisation, or else, as he called it, the 'disjuncture and difference in the global cultural economy.' Globalization has been equated with a shrinkage of time and space which in turn has created an interdependency between world economies, politics and cultures. Appadurai uses the concept of flows and deterritorialization to describe the process of globalisation which confers fluidity to relations and to the transfer of information and people. This is also related to the idea of 'time and space' - flows are moving and therefore not associated with one local and temporal point. He opposes this phenomena of globalisation to the notion of landscapes, predominant in the nationstate hegemony and to the perception of people, practices and ideologies as attached to lands. As an alternative, Appadurai coins the term: scapes. Through the lens of the concept of scapes, individuals are no longer assigned to one particular locality but instead seen as interacting with a deterritorialized environment where they participate in creating, reproducing and potentially modifying cultural apparatuses. The degree of individuals' participation in these cultural apparatuses can be correlated to the nature of the cultural form. In this sense, contemporary art can be seen as a 'hard cultural form.' This is to say that the bond between the value, the meaning and the practice itself is very strong. As such, it requires a thorough comprehension of the codes of this practice: its vocabulary, mechanisms, meanings and representations. If one wishes to transform or modify this practice, one must first appropriate and understand these codes. On the other hand, these global relations are marked by being indirect, and not specific to a time and space (Feldman 2011). At the same time, these flows are mediated through different means, such as the production, diffusion and consumptions of goods, the trade and transfer of commodities, the movement of people, the transfer of information thanks to the internet and technologies such as broadcast devices (films, TV, cd etc.). The condition sine qua non is to have the ideological frame in common, otherwise these relations cannot exist.

The contemporary art market represents a particular case within the general market. In the art market it is hard to make a distinction between the monetary value and the artistic value. The art market seems to have its own way of working with special actors involved in it: gallery-owners, auctioneers, collectors, private buyers, and states. It is seen as a special, mysterious phenomenon, and a controversial one at that, because of the nature of the art-piece and the prices involved, not to mention collectors, mostly from elite upper-class, creating artists' success or fall through their purchases. 
But the art market being only one function of the contemporary art world, has to be embedded in a more global frame: namely, the frame of global society and of the logics of world economy i.e. capitalism and neoliberalism. Indeed, the art market shares common characteristics with every other market: extreme concurrency, investments, speculations and monopolies (e.g. François Pinault and Jeff Koons). Olav Velthuis in Talking Prices (Velthuis 2007) argues that we can perceive the art market from different perspectives: from the classical economic point of view the market is an entity driven by universal laws and regulates itself. From the point of view of sociological economy, the market is an exchange system which is 'embedded in social networks' (Velthuis 2007, 3) and has a direct effect on the art dealer and all indicators of his success. From the author's point of view: which considers the market as 'cultural constellations' or 'social interaction', the market is 'ritualized' and 'it involves a wide variety of symbols that transfer rich meanings between people who exchange goods with each other' (Velthuis 2007, 3).

Following this logic, there are many 'cultural constellations:' some are satellites to other but for these constellations to exist, symbols, value systems, and representations have to be shared through global diffusion. But this does not happen without mediators that regulate and standardize these meanings. According to Alain Quemin in Lillusion de l'abolition des frontières dans le monde de l'art contemporain international: La place des pays "périphériques" à "l'ère de la globalisation et du métissage (2002), the attempts on the part of institutions that diffuse 'legitimate art,' such as museums, big cultural events and so on, to include international arts in a non-ethnocentric or non-essentialist ways have failed. These institutions or organizations that bring artefacts to these institutions such as the FNAC in France (Fonds National d'Art Contemporain) are solely promoting western artists. Indeed, even if the list of countries from which the FNAC received the art works includes 38 different nationalities, the 5 most represented countries have been the same for the last decade: United States, Germany, Great Britain, Italy and Switzerland. This might also reveal a potential misrepresentation of art from non-European countries (Quemin 2002, 19). Within the art market, only a specific type of art circulates, and/or art of specific geographical origin. Indeed, the 'art' in the term 'art market' is actually designating European and/or American art. Progressively, contemporary art presents itself (through actors and institutions) as very global and international but in practice remains very West and Eurocentric, not to mention located in the West.

From an etymological point of view, it is not incorrect to describe contemporary art as an international phenomenon as long as the nations in the term 'international' are defined. Contemporary art takes place in an international scale through big cultural events such as fairs and biennales. Thanks to these cultural meetings (including vernissages and exhibitions), artists have the opportunity to become known, not only thanks to the economic and national rivalries, but mostly because these events offer them physical places to socialize and nurture a social and professional network. There is a concentration of these cultural events in Europe and America, where some of the most important are located in Venice (Biennale of Venice, Italy), Kassel (La documenta, Germany), Basel (Art Basel, Switzerland), Madrid (ARCO, Spain), Paris (FIAC, France) etc. and they are all described as international and global contemporary art fairs. These events have an international impact on the contemporary art market and are contributing to the construction of standards in art and influence the choices of 
professionals, collectors and audiences. Moreover, artwork prices are significantly influenced by the trajectories of artists' careers, especially by their presence in fairs and big events. This legitimacy is provided by the reputation of the fair and of the other artists present in these meetings.

There is a paradox that says that actors within the contemporary art worlds have to be mobile and artists should be international, even hybrid, in order to be included within the contemporary art world. But according to discourses and practices of actors in art, it seems to be the case that what they mean translates in practice into relation between countries within Europe and possibly US, but rarely beyond. These practices and discourses reveal an entre soi and a centralization of power and representations that have come to become hegemonic. This entre soi is perpetuated and reproduced by institutions that are administrated by actors such as gallery owners, curators and so on, who are not aware of having an ethnocentric view (or are aware, but do not care), all the while parallel art worlds seem to emerge - which may all be more or less equally ethnocentric - not to mention those being structured not only along the ethnic lines, but also along the lines of class.

\section{The Myth of Globalisation: The Global-Local Paradox}

Concerning the Art Basel Fair, during the last three editions (2017, 2016, 2015), 359 galleries were present. Of the 359 galleries, 60,6\% were from Europe, 27,7\% from North America (Canada and USA), 7,2\% from Asia (including Dubai), 3,6\% from South America, and 1,1\% from Africa. Within Europe: Berlin, Paris and London represented $47,5 \%$ of the European galleries and 13,4\% were from Italy. In North America, 80\% of the galleries were based in New York City. ${ }^{1}$ Despite the Europe-US hegemony, this bias is not specific to these localisations. Indeed, through a comparison of three cultural events in three different locations: The Art Basel (Switzerland), the KIAF in Seoul (South Korea) and the World Art Dubai (United Arab Emirates), it is possible to say that every cultural event with the label 'global' or 'international' is actually promoting domestic art rather than global art. These events show that every art world is self-centred, and the so-called exchange can be qualified as competition.

This paradox can be seen in the descriptions by the official websites of the fairs and events. Concerning the KIAF, their introduction promoted mostly domestic art and Asian art and in the same time advertised the 'worldwide' aspect that is evoked in the title of the fair: 'Korean and International Art Fair'. The same rhetoric can be found in the introduction of the World Art Dubai with a focus on the prices as well as for the Art Basel Fair. But this is not only present in discourses provided by these cultural events, but also in representations of participants' nationalities or origins (artists and galleries). Concerning the World Art Dubai in 2017, over 48 galleries, 20 were from Arabicspeaking countries (Iran, United Arab Emirates and Qatar) which represent 42,7\% of the galleries. Europe represented $18,8 \%$ of the total and USA 4,2\%. Over 69 artists, 56,5\% were from Arabic-speaking countries, then, European artists represented 27,5\%

\footnotetext{
1 Statistic made by the author according to official numbers available online at: https:// www.artbasel.com/galleries?showld $=1,351,501$
} 
of the total. There was one artist from South Africa. ${ }^{2}$ In 2017, over 167 galleries present at the KIAF, $70 \%$ were from South Korea, 16,2\% from the rest of Asia and 14,7 from Europe and none from Africa or America. ${ }^{3}$ These events allow us to reject the idea of one and unique, global and inclusive, art world. Instead, they force us to think the tensions between the global and the local. Globalisation is not present in any of these art worlds, instead it is always about negotiation, ethnocentric promotion where the local usually wins over the global and where local artists are favoured.

An art world is defined by Howard Becker in his book Art Worlds (1982) as a cooperation of anyone who contributes to the making of an artwork. The emphasis is placed here on the social connections and social networks. Once outside Europe, this definition become less relevant. Indeed, institutions are not as dominant as in Europe, the social connections are marginalized and because of this, artists might have an important role in their art world. In order to complete this definition, more aspects should be included: the material and cultural components, hierarchy, interdependency, audiences and buyers. Therefore, the structure of the art worlds can be divided into three dimensions: the first one is the material dimension: artefacts (this can include visual art, installations and performances) and physical places to exhibit. The second dimension is a social dimension: artists, curators, gallery-owner, art-dealer, critics, audience. The third dimension is institutional and cultural: social norms, rules, policies, public administrations, institutions, moral and aesthetic dispositions and discourses. These three layers of art-worlds are interdependent - also in their representations. These representations are divided into two dimensions. The first one refers to an imaginary collective, that is to say social representations. This is a societal phenomenon that requires common objective conditions and has to be collectively shared. To approach social representations linked to the cultural industry and art means to analyse art and fictions, novels, movies and so on, that participate in shaping an imaginary. The second representation is individual and subjective: how an artist represents him-herself, how he/she describes his/her trajectory. This self-representation obeys more or less certain norms, ideologies and prejudices such as the ideas of 'vocation' and 'genius', which are a strong source of explanation for artists and art-workers as well.

This general structure can be found in various localities in the world; each layer can be more or less developed. This is to say, the artefacts, the artists and the moral and aesthetic dispositions assigned to a locality differ from one place to another. While observing these variations, 'the art world' must be seen as plural; talking about 'the art world' as one becomes impossible. Every art world follows the same objective structure but the interplay between the layers generates variations. For example, the material dimension is subject to tree distinct phenomena described by George Marcus and Fred Myers in The Traffic in Culture: Refiguring Art and Anthropology (1995). The first one is appropriation: how artworks are incorporated into contemporary art and exhibited in galleries, museums etc. Secondly, boundaries, or else the fact that some artworks are

\footnotetext{
2 Statistic made by the author according to official numbers available online at: https:// www.worldartdubai.com/exhibitors?\&filters.status $=$ Gallery\&searchgroup $=00000001$-exhibitors

${ }^{3}$ Statistic made by the author according to official numbers available online at: http://kiaf.org/2017/en/ exhibitors_en/
} 
excluded from the contemporary art and the limits imposed upon circulation of the artworks that are included, as well as the type of museums where contemporary artworks are exhibited (African contemporary artists may be circulated in Europe, but exhibited in the less prestigious ethnographic museums). These elements determine and are determined by the other layers.

Charlotte Bydler in The Global Art World Inc.: On the Globalization of Contemporary Art (2004) talks about 'national discourses' and includes the economic aspect in her analysis when she talks about the art market. She notably discusses the core when she talks about art worlds, this core would be the United States, while the other art worlds are described as peripheral. She shows that even within Europe, Eastern Europe is peripheral when it comes to the art world. When she talks about the art world, she does not mean the whole world but specific location that become dominant with power to administer and decide over other locations. Hegemonic discourses are mostly generated in the United States, others being subordinated. The 'artscape' is therefore the sum of all the exchanges between these art worlds. Artworks are exchanged and flow through the art market and cultural events, artists flow thanks to migration and cultural events, and finally, art value flows through images, information, ideologies and discourses. Regarding these first conclusions, it is important to (re)define globalization from the perspective of the art worlds. In Globalization and Contemporary Art: A Convergence of Peoples and Ideas Jonathan Harris claims that globalisation should be understood within three qualifications (Harris 2011). Firstly, it refers to societies' organisations in many other fields than art. Secondly, societies are shaped by their history which is marked by colonial history and imperialism from the so called West. Thirdly, despite the massive use and diffusion of the idea of globalization through education and media, its meaning remains blurred. Therefore, globalization should be understood as an analytic construct concerning world's mechanisms and communications.

\section{Perverse Effects of the Idea of Globalisation and the Art of Vooria Aria}

Once the analytic construct has been defined in such terms, it is important to highlight that every art world in times of globalisation cannot be disconnected from the local historical political and material reality. 'These processes do not exclude frictions, compromises and inequalities; they still respond to remaining colonial configurations and segregations, and to economic and structural disproportions that determine the power to legitimate art. The term "glocal" blurs these contradictions, since it connotes a fluid and universal connection between the two terms that it mixes together' (Mosquera, 2). From this perspective, one cannot deny the multiplicity of art worlds while talking about the resistance regarding the entrance of an artist from a certain art word to another. This resistance is mainly driven by stereotypes concerning artists and their artwork based on their nationality and origins. Many mechanisms involving both individuals' and society's responsibility for this can be observed. They might result in integration or non-integration of the artist and his or her artwork. The integration can be achieved via what can be qualified as voluntary conformity and self-essentialization which stereotypes both the artist and the artwork, or involuntary conformity and essentialization when the artist and artwork are matching the stereotypes and expectations from another art world linked to collective representations. Concerning the non-integration, it is a result of a confrontation between stereotypes, expectations from 
an art world and hybrid identities of artists with an origin misrepresented in the same art world. Indeed, for artists who have lived, been socialized and benefited from an education in different localities around the world, their art is a hybrid mix from different backgrounds that cannot be categorize in any nationalistic tradition.

Vooria Aria, exhibiting in the Artists' Waste, Wasted Artists exhibition, was born in Iran and moved to Vienna in 2003 at the age of 24. He has exhibited in Europe (Austria, England, Sweden), and Middle East (Iran, Pakistan, Turkey). According to him, his art is not linked to any traditional or Middle Eastern ideas or events but to his childhood; his father was a civil engineer working on building sites. He uses three qualifications in order to choose the material he uses: physical properties of the chosen materials, his memories linked to this material and his self-identification. His main concern is to be able to produce an aesthetic work that he describes as bi-dimensional: conceptual and physical, with a necessity of continuity between those two. The carpet at the entrance to the exhibition you probably stepped on, was produced respecting these conditions. The first goal of this carpet was for Vooria to materialize his conception of identity which is to him 'perishable'. The material is cheap and faded quickly, it changes the image of his portrait that figures on it and can be seen as valueless from the point of view of a stranger who does not recognize a familiar face. For the artist, this means 'getting a new identity.' In this discourse and self-representation, there is no nationalistic perspective. Nonetheless, he is often participating in exhibitions and projects treating issues such as intercultural interactions, national identities and political conflicts. In Europe, the emphasis is placed on his origin, Iran, and in Arabic countries, it is on his place of living, which is Europe and Austria. In both case this reduces him to features that are not self-revindicated. It is either conformity to stereotypes which help artists and artworks to be integrated or a hybridization and non-conformity that prevent them to be integrated into a certain art world and in contemporary art in general. Non-integration is one of the key factors in invisibility, therefore perpetuating the prejudices and stereotypes about non-western but also western art and artists with migration backgrounds and hybrid identities. But, "most of this activity is "local" in the sense that it is the result of artist's' personal and subjective reactions to their contexts, or because it seeks to create a cultural, social, or even political impact in the artists' milieus. But these artists are frequently well informed about other contexts, about mainstream art, and are also looking for an international audience. Sometimes they move in and out between local, regional and global spaces' (Mosquera, 2). This carpet has to be understood within the conceptual frame of the exhibition which is questioning the process of value creation. Firstly, the value brought about by the artist himself through the choice of materials and meanings, but also the value that each of us, are putting on this artist and his artwork that, as individuals embedded in collective European ideologies - bias, loaded with connotations and prejudices.

According to Roland Robertson in Glocalization: Time-space and Homogeneity-heterogeneity (1995), using the concept of glocalization highlights precisely these tensions, everything falls under social construction and narratives especially concerning the legitimacy of contemporary art and the debate about contemporary art versus world art that the author describes as USA-Euro-centred. The idea of homogenization through globalisation that is confronted with heterogeneity from nationalistic impulses must be overcome. Robertson talks about an interplay between the two. 'Global lies beyond all 
localities' (Robertson, 1995: 34), to define globality like this helps us to get rid of the conflict modernity has commonly seen as inherent of globality vs. tradition inherently associated with locality, one which is also used to exclude artwork of contemporary art in times of globalisation.

Appadurai, Arjun. 1996. Modernity at Large: Cultural dimensions of globalisation. Minneapolis: University of Minnesota Press.

Becker, Howard. 1982. Art Worlds. Berkeley: University of California Press.

Bydler, Charlotte. 2004. The global art world Inc. On the globalization of contemporary art. Stockholm: Acta UniversitaIs Upsaliensis.

Enwezor, Okwui. 2003. 'The postcolonial constellation: contemporary art in a state of permanent transition' in Research in African Literatures, Indiana University Press.

Feldman, Gregory. 2011. 'If ethnography is more than participant-observation, then relations are more than connections: the case for nonlocal ethnography in a world of apparatuses', Anthropological Theory 11(4): 375-395, DOI: $10.1177 / 1463499611429904$.

Harris, Glare. 2013. In and out of Place: Tibetan Artists' Travels in the Contemporary Art World, London: Bloomsbury Academic.

Harris, Jonathan. 2011. Globalization and Contemporary Art: A Convergence of Peoples and Ideas, Oxford: John Wiley \& Sons, Ltd.

Marcus, George. Myers Fred. 1995. The Traffic in Culture: Refiguring Art and Anthropology, Berkeley: University of California Press.

Mosquera, Gerardo. N.D. 'Beyond Anthropophagy: Art, Internationalization and Cultural Dynamics', http://www.summeracademy.at/media/pdf/pdf776.pdf

Quemin, Alain. 2001. 'Le rôle des pays prescripteurs sur le marché et dans le monde de l'art contemporain,' Rapport au ministère des Affaires étrangères, Université de Marne-la-Vallée LATTS, Paris

Quemin, Alain. 2002. 'L'illusion de l'abolition des frontières dans le monde de l'art contemporain international:La place des pays "périphériques" à "l'ère de la globalisation et du métissage", In the review Sociologie et sociétés 34(2): 15-40.

Robertson, Roland. 1995. Glocalization: Time-space and Homogeneity-heterogeneity. London: Sage.

Velthuis, Olav. 2005. Talking Prices: Symbolic Meanings of Prices on the Market for Contemporary Art. Princeton: Princeton University Press. 